\section{Miten omakuva esittää?}

\section{Marja Lahelma}

Patrik Nyberg, Maalatut kasvot: Helene Schjerfbeckin omakuvat, modernismi ja esittäminen, Helsinki: Kansallisgalleria 2019, 239 sivua.

Patrik Nybergin lokakuussa 2019 ilmestynyt väitöskirja Maalatut kasvot: Helene Schjerfbeckin omakuvat, modernismi ja esittäminen rakentaa monitahoisen teoreettisen kudelman, jonka kautta Schjerfbeckin omakuvataide näyttäytyy aivan uudenlaisessa valossa. Aiheensa puolesta tutkimus olisi tuskin voinut osua ajankohtaisempaan saumaan, sillä Schjerfbeck on juuri nyt pinnalla. Laaja taiteilijan tuotantoa esitellyt näyttely oli esillä Lontoon Royal Academyssa vuoden 2019 heinäkuusta lokakuulle, ja sen jälkeen näyttely siirtyi laajennettuna ja hieman eri muodossa Helsinkiin Ateneumin taidemuseoon. Nyt kun kansainvälinenkin huomio on tällä tavoin kohdistettu suomalaisten rakastamaan taiteilijaan, uudet näkökulmat ovat tervetulleita.

Schjerfbeckin laaja omakuvatuotanto on aina herättänyt erityistä kiinnostusta niin tutkijoiden kuin ylei-

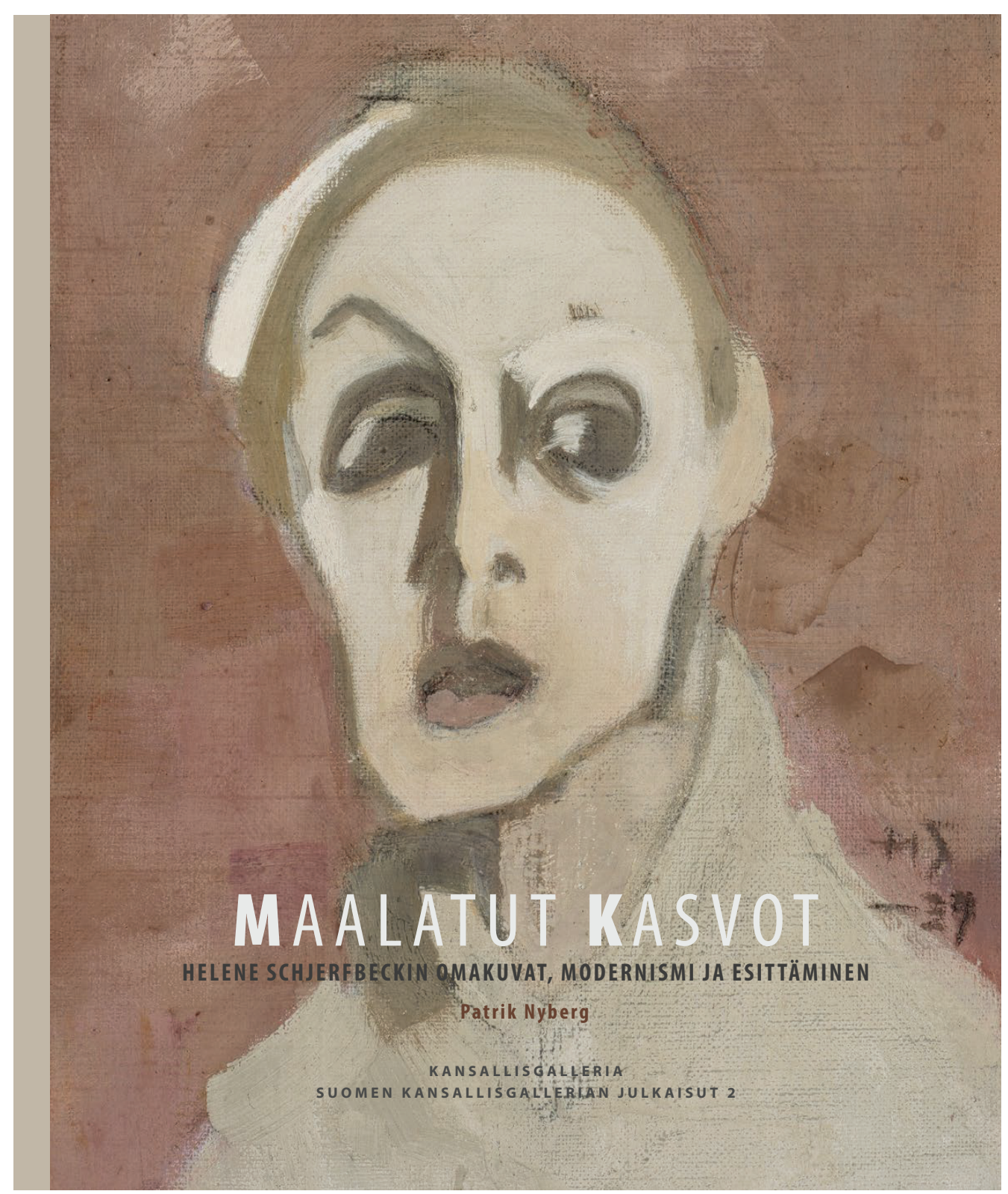


sönkin keskuudessa. Nybergin tutkimus tuo kuitenkin selkeästi esiin aiempien tulkintojen puutteet. Vaikka Schjerfbeckin omakuvia on pidetty poikkeuksellisina, niiden ominaislaatua on analysoitu yllättävän vähän. Omakuvia on tarkasteltu pääosin elämäkerrallisesta näkökulmasta, ja myöhäisissä omakuvissa vanhenemisen tematiikka on ollut tulkinnoissa tärkeässä osassa. Mutta mistä lopulta päättelemme Schjerfbeckin myöhäisten omakuvien esittävän vanhenevaa naista? Nybergin huomautus, ettei kuvissa itsessään ole mitään ikään tai vanhuuteen viittaavaa, on suorastaan silmiä avaava. Hän toteaakin väitöskirjansa johdannossa, että tutkimuksen käynnistävänä voimana on ollut spontaani inmettely Schjerfbeckin teosten äärellä. Taidehistorian perinteiset kysymyksenasettelut tuntuivat rajoittavan tulkintamahdollisuuksia ja peittävän alleen teosten moniulotteisuuden. Jotta Schjerfbeckin omakuvien merkityksellisyys saisi ansaitsemansa painoarvon, niitä on luettava tavoilla, jotka ylittävät omakuvan vakiintuneet tulkintamallit. Samalla modernistinen kertomus itsessään asettuu kyseenalaiseksi.

\section{Maalattu kuva}

Schjerfbeckin omakuvien kriittinen tarkastelu tarjoaakin erinomaisen pohjan modernismin diskurssien uudelleenarvioinnille, sillä ne eivät noudattele teleologista näkemystä modernismin kehityksestä esittävyydestä kohti abstraktiota. Nybergin luennassa pelkän optisen havainnoinnin sijaan kuvista avautuu niiden materi- aalisuuteen perustuva haptinen taso. Schjerfbeckin omakuvat etääntyvät mimeettisestä esittämisestä ja korostavat teoksen materiaalista ja aistimellista olemusta. Esittävyys ja erityisesti henkilöaihe, kuitenkin säilyttävät merkityksensä.

Keskeiseksi Nybergin kirjassa nousee kysymys siitä, mihin Schjerfbeck omakuvissaan oikeastaan paikantuu. Onko hänen läsnäolonsa olennaisemmin kiinnittynyt kuvassa näkyvään hahmoon, vai ehkä pikemminkin maalaamisen materiaalisiin jälkiin? Teosten merkityksellisyyttä ei haeta ulkoisista faktoista, kuten elämäkerrallisista seikoista, vaan tarkastelun keskiössä on teoksista itsestään kumpuava problematiikka. Kiinnittämällä huomion omakuvien esittämistapaan kytkeytyvään merkitysulottuvuuteen - eli siihen miten omakuva esittää - päästään käsiksi esittävien ja ei-esittävien omakuvien representaatiokriittiseen potentiaaliin. Omakuvien tapaa tuottaa merkityksiä lähestytään kiinnostavasti materiaalisuuden ja mimeettisen esittävyyden välisenä dynamiikkana. Nyberg kutsuu tätä tarkastelun kohteena olevaa ilmiötä maalatuksi kuvaksi. Tutkimus soveltaa luovasti jälkimodernin taiteen käsittelyyn syntynyttä teoriaa teoksiin, jotka ajallisesti edeltävät tällaista teorianmuodostusta. Valinta on täysin tietoinen ja erittäin onnistunut, sillä se tekee kunniaa teosten moniulotteisuudelle. Kuten kirjoittaja toteaa, kriittisyys ja purkava asenne eivät ole yksinomaan jälkimodernin taiteen ominaisuuksia.
Nybergin lähestymistapa ei perustu mihinkään olemassa olevaan metodologiseen malliin, vaan tutkimus purkaa ja rakentaa uudelleen tulkintakehystä dialogissa teoreettisten pohjatekstien kanssa. Tutkimuskohteena olevaan materiaaliin soveltuvan metodologisen välineistön ja käsitteistön luomisesta muodostuu siten yksi väitöskirjan keskeisistä saavutuksista. Tärkeimpinä keskustelukumppaneina ovat W. J. T Mitchellin, Mieke Balin, Hubert Damischin, Jacques Derridan ja Jean-Francois Lyotardin kaltaiset kuvan merkityksenmuodostusta sekä kuvan ja sanan eroja tai risteyskohtia pohtineet teoreetikot. Näiden lähtökohtien pohjalta syntyvässä tulkintamallissa kuvat näyttäytyvät diskursiivisina, mutta niiden ilmaisukykyä ei kuitenkaan ymmärretä reduktiivisesti verbaalisen kielen kaltaisena. Lyotardin figuraalisuuden käsite tarjoaa oivallisen työkalun maalatun kuvan ilmiön hahmottamiseen. Tällöin kuvan merkityksenmuodostus asettuu dynaamisen liikkeeseen, joka hajottaa sekä muodon että diskursiivisen määrittymisen pysyvyyttä.

Kuvan ja sanan dynamiikkaa pohtivan teoriakehyksen kanssa limittäin asettuu keskustelu identiteetin performatiivista määrittymistä teoretisoineen Judith Butlerin näkemysten kanssa ja toisaalta lacanilaiseen psykoanalyysiin nojautuva subjektiuden ja ruumiillisuuden kriittinen tarkastelu. Omakuvan ymmärtäminen katsojalle osoitettuina performatiiveina ja tekijänsä identiteettiä tuottavina tekoina on Schjerfbeckin teos- 
ten kohdalla erityisen havainnollinen lähestymistapa, sillä ne eivät oikein suostu asettumaan perinteisen representaation puitteisiin. Schjerfbeckin omakuvien tarkastelun pohjalta Nyberg ehdottaa, että näennäisen perinteinenkin maalattu omakuva voi esittää kriittisiä kysymyksiä subjektin olemuksesta. Tutkimus kokoaa ansiokkaasti yhteen omakuvaan liittyvää teoriaa, ja tarjoaa myös tätä kautta hyödyllisiä lähtökohtia jatkotutkimukselle.

\section{Kärsivällinen lukija palkitaan}

Nybergin käyttämä kieli on varsin huoliteltua ja tyyliltään hienostunutta. Monimutkaiset ajatukset ja argumentit ovat löytäneet sujuvan ja luontevan kielellisen muodon. Lukijaa ei tosin päästetä aivan helpolla. Teoriataustan esittely on hyvinkin seikkaperäistä, ja välillä on pitkiä jaksoja, joissa Schjerfbeckiä ei mainita lainkaan. Sen tähden on joiltain osin vaikeaa hahmottaa teoriataustoituksen relevanssia tutkimuksen varsinaisen aiheen, eli Schjerfbeckin omakuvien kannalta. Erityisesti lacanilaiseen psykoanalyysiin kiinnittyvä teoretisointi jää osin irralliseksi ja tuntuu ehkä tarpeettomankin perusteelliselta. Kirjoittajalle itselleen sen syvällinen haltuunotto on epäilemättä ollut tarkoituksenmukaista.

Lisäksi lukijaa saattaa jäädä askarruttamaan, miksi teoreettinen kehys painottuu sellaisiin keskusteluihin, jotka olivat voimakkaasti esillä 1980- ja 1990-luvuilla, eikä aivan uusinta teoriakirjallisuutta käsitellä kuin muutamien nimekkeiden osalta. Etenkin modernismin kysymysten kohdalla tutkimus ei näin ollen osallistu aivan viimeaikaisiin keskusteluihin. Kuvataiteen modernismin abstraktiota kohti kulkevaa narratiivia on sitten viime vuosituhannen lopun alettu koetella jo aika monestakin suunnasta. Valittua teoriataustaa voi tosin puolustaa sillä, että kyseessä ovat tietyn teoriaorientaation klassiset teokset. Nybergin tutkimuksessa näitä teorioita sovelletaan sellaiseen aiheeseen, johon niitä ei ole aiemmin sovellettu. Tutkimuksessa käytetty teoriakehys onkin sinänsä aivan toimiva, mutta sitä olisi ehkä voinut vielä hieman painokkaammin perustella.

Nyberg hallitsee käyttämänsä käsiteapparaatin poikkeuksellisen hyvin. Hienoa on myös se, miten tutkimus käy jatkuvaa kriittistä vuoropuhelua teoriataustan kanssa. Analyysiosuudessa teoriakehystä sovelletaan monipuolisesti ja syvällisesti reflektoiden suhteessa teoksiin. Lukija siis saa lopulta palkintonsa, vaikka siihen ehkä vaaditaan hieman kärsivällisyyttä. Aivan erityisen vaikutuksen Nybergin tutkimusotteessa tekee se kunnioitus ja vakavuus, jolla hän suhtautuu kohteena oleviin teoksiin. Tuntuu suorastaan huojentavalta jättää tekijän biografia vaihteeksi täysin sivuun ja sulkeistaa kysymys esimerkiksi taiteilijan sukupuolesta, sillä juuri naistaiteilijoiden kohdalla elämäkerrallisuudella on ollut taipumus dominoida tulkintoja. Tässä mielessä Nybergin tutkimusotteen syvällisyyttä ja analyysin huolellisuutta voidaan pitää suorastaan fe- ministisenä tekona. Lisäksi ilmeisenä ansiona voidaan mainita se, että Nybergin tutkimus tuo tietynlaista teoriapuhetta osaksi suomalaista keskustelua ja "kääntää" sitä suomen kielelle. Toivottavaa olisi, että Nyberg laatisi tutkimustyönsä pohjalta myös kansainvälisiä julkaisuja, sillä kuten edellä jo todettiin, Schjerfbeck herättää nyt kiinnostusta maailmalla.

FT Marja Lahelma on Helsingissä asuva taidehistorian tutkija ja tietokirjailija. Hän on käsitellyt tutkimuksissaan minuuden ja identiteetin kysymyksiä sekä omakuvan problematiikkaa.

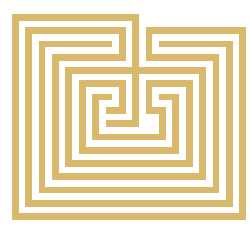

